\title{
Antibodies Against a Synthetic Peptide of the Poliovirus Replicase Protein: Reaction with Native, Virus-Encoded Proteins and Inhibition of Virus-Specific Polymerase Activities In Vitro
}

\author{
MARGARET H. BARON AND DAVID BALTIMORE* \\ Center for Cancer Research and Department of Biology, Massachusetts Institute of Technology, Cambridge, \\ Massachusetts 02139
}

Received 16 February 1982/Accepted 18 May 1982

\begin{abstract}
A carboxy-terminal peptide of the poliovirus replicase protein (p63) was chemically synthesized, coupled to bovine serum albumin carrier, and injected into rabbits. The resulting antisera reacted with six virus-specific proteins from HeLa cells infected with poliovirus: NCVP $0 b$, NCVP $1 b$, NCVP 2, a protein of about 60,000 daltons, p63, and NCVP $6 \mathrm{~b}$. The identity of the 60,000 -dalton protein is not known, but the other results were consistent with previous experimental approaches which demonstrated that $\mathrm{p} 63$ and the other four polypeptides have common coding sequences. An amino-terminal peptide of p63 failed to elicit an immune response in rabbits. Antibodies raised against the p63 carboxy-terminal peptide inhibited poliovirus replicase and polyuridylic acid polymerase activities in vitro, providing strong support for earlier suggestions that these activities are a property of a single virus-specific polypeptide.
\end{abstract}

The RNA-dependent RNA polymerase encoded by poliovirus is the only animal virus replicase to have been isolated and purified in a template-dependent form. Highly purified preparations of poliovirus replicase are active in the presence of poliovirion RNA and oligouridylic acid [oligo(U)] $(17,22,43)$, which acts as a primer for RNA synthesis in vitro (M. H. Baron and D. Baltimore, J. Biol. Chem., in press). The requirement for oligo(U) can be replaced by adding a protein fraction ("host factor") from uninfected HeLa cells (17); this host factor is found free in the cytoplasm (M. H. Baron and D. Baltimore, J. Biol. Chem., in press). The RNA product of either the oligo(U)- or host factorstimulated reaction is largely double-stranded in character and a full-length copy of the positivestrand RNA template, and represents the entire viral genome (Baron and Baltimore, in press). In the presence of host factor, the poliovirus replicase will also copy purified negative-strand RNA to give full-length positive-strand RNA (M. H. Baron, E. A. Scodeller, and D. Baltimore, unpublished data). The replicase copurifies with a polyadenylic acid [poly(A)] oligo(U)dependent polyuridylic acid [poly(U)] polymerase activity $(16,17,20-22,43)$. Both of these activities are associated with the viral protein p63 but not with noncapsid viral protein (NCVP) 2, which is also present in many preparations of replicase-poly(U) polymerase (43).

To learn more about the poliovirus replication proteins and their interrelationships, we sought methods for the preparation of specific antibodies against some of these viral gene products. Highly purified preparations of poliovirus replicase contain only minute amounts of p63 and NCVP 2 (unpublished data), although both proteins are easily detected by radiolabeling. Direct immunization of laboratory animals with the authentic viral protein did not appear to be feasible; therefore, we resorted to chemical synthesis of $\mathrm{p} 63$ peptides.

It is now well established that antibodies raised against peptides conjugated with macromolecular carriers may react not only with the homologous peptides but also with the proteins from which the peptides were originally isolated $(1-3,5,23,30,45)$. Even synthetic peptides, when conjugated to a larger carrier polymer, can be used to elicit the formation of antibodies which are capable of reacting with the native protein $(4,19)$. It should therefore be possible, at least in principle, to prepare antibodies against any protein for which the amino acid sequence is available. By extension, the availability of a nucleic acid sequence, from which the amino acid sequence can be deduced, should and does simplify matters further $(29,41,44)$. Indeed, we recently reported that antibodies raised against the chemically synthesized genome-linked protein of poliovirus $(\mathrm{VPg})$ react with native virusspecific proteins (12).

The complete nucleotide sequence of the po- 
liovirus genome was recently reported $(25,34)$, and the partial amino acid sequence determination was used to precisely map the amino terminus of the replicase protein p63 $(25,38)$. NCVP 2 , which contains the entire p63 sequence $(25$, 39 ), is the most $3^{\prime}$-proximal gene product (42); this fact, taken together with the molecular weight of p63 calculated from its mobility during sodium dodecyl sulfate (SDS)-polyacrylamide gel electrophoresis (21), indicates that the last amino acid of p63 must virtually coincide with the very end of the genomic coding region $(25$, $26,34)$. We used solid-phase methods $(11,40)$ to prepare a 13-residue amino-terminal peptide and a 12-residue carboxy-terminal peptide [p63(N) and p63(C), respectively]. Rabbits were immunized with bovine serum albumin (BSA) conjugates of the peptides. Antibodies were successfully raised against p63(C) but not against p63(N). Anti-p63(C) sera reacted with authentic p63 as well as with NCVP 0b, NCVP $1 b$, and NCVP 2, each of which contains the entire p63 sequence $(25,39)$. Two other proteins, of approximate molecular weights 60,000 and 30,000 , were also recognized by the anti-p63(C) sera. The identity of the larger polypeptide is unknown, but the smaller protein is probably NCVP 6b, believed to be an alternative cleavage product of NCVP 2 (38).

Affinity-purified anti-p63(C) antibodies inhibited both replicase and poly(U) polymerase in vitro, supporting the earlier suggestion (21) that the two enzymatic activities are a property of a single protein.

\section{MATERIALS AND METHODS}

Materials. $\quad N^{\alpha}$-Butyloxycarbonyl (tBoc)-L-amino acid derivatives were purchased from Bachem Fine Chemicals. $\left[{ }^{14} \mathrm{C}\right] N^{\alpha}$-tBoc-L-alanine was prepared as described previously (12).

$\left[{ }^{14} \mathrm{C}\right] N^{\alpha}$-tBoc-L-leucine was prepared from $\left[U-{ }^{14} \mathrm{C}\right] \mathrm{L}$-leucine (Amersham Corp.; $330 \mathrm{mCi} / \mathrm{mmol}$ ) and di-t-butyl-dicarbonate (Pierce) by a modification of the procedures of Pozdnev (33) and Moroder et al. (31), with a yield of $56 \%$ and a specific activity of 110 $\mathrm{cpm} / \mathrm{nmol}$.

Triethylamine, trifluoroacetic acid, and $\beta$-mercaptoethanol were redistilled and stored under nitrogen. The sources of other reagents have already been documented (12).

Amino acid coupling. Solid-phase peptide synthesis was conducted by previously reported methods (11, 39), essentially as described by Baron and Baltimore (12). Phenylalanine resin (5g) was used for the synthesis of p63(N), and $10.7 \mathrm{~g}$ of resin was used for the synthesis of p63(C). The synthesis of p63(C) was complicated by the presence of tryptophan, which is readily oxidized in the presence of trifluoroacetic acid. Therefore, $1 \%$ (vol/vol) $\beta$-mercaptoethanol was added to the trifluoroacetic acid- $\mathrm{CH}_{2} \mathrm{Cl}_{2}$, and acid treatments were followed by three washes with $1 \%$ (vol/ vol) $\beta$-mercaptoethanol- $\mathrm{CH}_{2} \mathrm{Cl}_{2}$ and then by three washes with $\mathrm{CH}_{2} \mathrm{Cl}_{2}$ alone.
Cleavage and deprotection. Peptide resins (2.5-g portions) were cleaved in liquid $\mathrm{HF}-10 \%$ anisole at $0^{\circ} \mathrm{C}$ for $1 \mathrm{~h}$. After removal of excess $\mathrm{HF}$ under reduced pressure, the peptide resin mixture was extracted three times with ether to remove remaining anisole and free amino acid side chain protecting groups, and the peptide was extracted into glacial acetic acid and lyophilized. Recovery (as monitored by liquid scintillation counting of ${ }^{14} \mathrm{C}$-labeled amino acid) was virtually quantitative.

Purification of the peptides. (i) Amino-terminal peptide. Crude peptide recovered after cleavage of $2.5 \mathrm{~g}$ of peptide resin was redissolved in $5.5 \mathrm{ml}$ of $10 \%$ acetic acid and chromatographed on a $2.5-$ by $50-\mathrm{cm}$ column of Sephadex G-25 in $10 \%$ acetic acid as described previously (12). The peptide peak was divided into three pools, each of which was subjected to amino acid analysis. The central $87 \%$ of the peak was chosen for further purification. One-half of the Sephadex G-25 pool II was lyophilized several times from distilled water, redissolved in $4.5 \mathrm{ml}$ of $0.1 \mathrm{M}$ ammonium formate ( $\mathrm{pH} 3.1)$, and applied to a column (1.5 by 17 $\mathrm{cm})$ of BioRad AG-50WX2 resin equilibrated with the same buffer. After being washed with equilibration buffer, the column was eluted with buffers of decreasing ionic strength and increasing $\mathrm{pH}$ (ammonium formate to $\mathrm{pH}$ 3.5; ammonium acetate thereafter). The peptide eluted in $0.1 \mathrm{M}$ ammonium acetate, $\mathrm{pH}$ 8.5. The purified peptide was repeatedly lyophilized to remove salt and stored frozen in water at a concentration of $32 \mathrm{mg} / \mathrm{ml}$.

(ii) Carboxy-terminal peptide. Crude peptide was again subjected to gel filtration on Sephadex G-25$10 \%$ acetic acid, and the central $65 \%$ of the peptide peak was used for further purification. This peptide was only sparingly water-soluble above $\mathrm{pH}$ 5.5. A portion (42\%) of the Sephadex G-25 pool was adjusted to $50 \mathrm{mM}$ ammonium acetate $(\mathrm{pH} 5.5)$ and then applied to a column $(1.5$ by $19 \mathrm{~cm})$ of Biorex 70 equilibrated with the same buffer. The column was eluted first with ammonium acetate buffers of decreasing $\mathrm{pH}$ and then with increasing amounts of acetic acid. The peptide was recovered in $50 \%$ acetic acid and was lyophilized repeatedly to decrease the concentration of acid. Because it was not soluble in water alone, the peptide was stored as a powder at room temperature.

Amino acid analysis. Amino acid analyses were performed by Erlinda Capuna in the laboratory of Lisa Steiner, Massachusetts Institute of Technology (Table 1). The final recovery of purified amino-terminal peptide, representing one-half of the Sephadex G-25 pool II, was $89.8 \mathrm{mg}(23.7 \%)$. The final recovery of carboxy-terminal peptide, representing $42 \%$ of the Sephadex G-25 pool II, was $14.5 \mathrm{mg}$ (10\%).

Peptide analysis. Peptides were analyzed by highvoltage paper electrophoresis and by silica thin-layer chromatography in several solvents, as described in an earlier report (12).

Conjugation of peptides with bovine serum albumin. The amino-terminal peptide was coupled to BSA (Pentex) with glutaraldehyde exactly as described previously (12). The efficiency of coupling was low (20\%) for reasons which are not clear. The carboxy-terminal peptide could not be coupled under the usual conditions because of solubility problems. The following procedure was quite successful, with an unexpectedly high coupling efficiency of $65.8 \%$. The peptide was 
TABLE 1. Amino acid analysis of the synthetic peptides $^{a}$

\begin{tabular}{llcc}
\hline \multirow{2}{*}{$\begin{array}{c}\text { Synthetic } \\
\text { peptide }\end{array}$} & Amino acid & \multicolumn{2}{c}{ Molar ratio } \\
\cline { 3 - 4 } & & Theoretical & Calculated $^{b}$ \\
\hline p63(C) & Arg & 2 & 1.80 \\
& Asn & 1 & 1.05 \\
& Thr & 1 & 1.08 \\
& Ser & 2 & 1.89 \\
& Leu & 2 & 2.15 \\
& Tyr & 2 & 2.14 \\
& Phe & 1 & 0.96 \\
p63(N) & Trp & 1 & 1.18 \\
& Asn & 1 & \\
& Thr & 1 & 0.96 \\
& Ser & 2 & 0.98 \\
& Glu & 1 & 1.94 \\
& Pro & 2 & 1.08 \\
& Ala & 2 & 2.00 \\
& Leu & 1 & 1.88 \\
& Phe & 1 & 1.03 \\
& Lys & 2 & 0.98 \\
& & 1 & 2.05 \\
\hline
\end{tabular}

${ }^{a}$ See Fig. 1 for sequence.

${ }^{b}$ Molar ratio based on average of 12 residues for p63(C) and 14 residues for p63(N).

suspended in $4 \mathrm{ml}$ of $0.1 \mathrm{M}$ sodium phosphate (pH $7.5)-50 \%$ (vol $/ \mathrm{vol})$ methanol at $37^{\circ} \mathrm{C}$. Approximately $90 \%$ of the material $(5.2 \% \mu \mathrm{mol})$ was soluble under these conditions. BSA is not normally soluble in $50 \%$ methanol; however, we were able to add the carrier protein quickly and in concentrated form $(0.1 \mathrm{ml}$ of BSA [ $50 \mathrm{mg} / \mathrm{ml}$ ], $75 \mathrm{nmol}$, in $0.1 \mathrm{M}$ sodium phosphate, pH 7), followed by the addition of $15.2 \mu$ l of $2.5 \%$ glutaraldehyde. The reaction proceeded at $37^{\circ} \mathrm{C}$ for 1 h, with no evidence of precipitation. Shortly after transfer to a dialysis bag there was considerable precipitation, eventually resulting in a milky suspension. The suspension was dialyzed against phosphate-buffered saline for 2 days at room temperature and used directly for immunization of rabbits.

Immunization. Two-month-old New Zealand White rabbits were immunized with $420 \mu \mathrm{g}$ of conjugated amino-terminal peptide or $240 \mu \mathrm{g}$ of carboxy-terminal peptide, emulsified in complete Freund adjuvant, by intradermal injections at multiple sites. A sample of serum was obtained from each animal before immunization. The animals were boosted with $240 \mu \mathrm{g}$ of amino-terminal peptide or $120 \mu \mathrm{g}$ of carboxy-terminal peptide in incomplete adjuvant, starting 4 weeks after the priming immunization and repeated at 2- to 4-week intervals thereafter. Antisera were drawn 7 to 10 days after immunization, allowed to coagulate, clarified by centrifugation at $20,000 \times g$ for $15 \mathrm{~min}$, adjusted to 2 $\mathrm{mM}$ phenylmethylsulfonyl fluoride- $0.1 \%$ aprotinin, and stored in aliquots at $-20^{\circ} \mathrm{C}$.

Antibodies against purified type 1 poliovirus were prepared as described previously (12).

Iodination of amino-terminal peptide. The aminoterminal p63 peptide was iodinated by the procedure of Bolton and Hunter (13).

Labeling of poliovirus- and mock-infected HeLa cells. The growth of HeLa cells in suspension in Joklik modified Eagle medium with 5\% horse serum and infection by poliovirus were as described by Baltimore et al. (9). Labeling of virus-infected cells in the presence of $\left[{ }^{35} \mathrm{~S}\right]$ methionine and the subsequent preparation of cell lysates have already been described (12).

Mock-infected cell lysates were labeled with $\left[{ }^{35}\right.$ S]methionine as described by Baron and Baltimore (12).

Nonspecific immunoprecipitation of capsid proteins was prevented by pretreatment of total infected cell lysates with anti-poliovirion type 1 serum, as described previously (12).

Immunoprecipitation. Samples were diluted with $1 \%$ Triton X-100-0.1\% SDS-1\% sodium deoxycholate-2 $\mathrm{mM}$ phenylmethylsulfonyl fluoride- $0.1 \%$ aprotinin$0.05 \% \mathrm{NaN}_{3}$ in phosphate-buffered saline to a volume of 100 to $200 \mu \mathrm{l}$ and incubated at room temperature for $60 \mathrm{~min}$ with $5 \mu \mathrm{l}$ of anti-peptide serum or $5 \mu$ of preimmune serum unless otherwise indicated. Adsorption of immune complexes by fixed Staphylococcus aureus was performed as described previously (12).

For competition experiments, lyophilized carboxyterminal peptide (insoluble in water) was suspended in phosphate-buffered saline by vigorous mixing. Undissolved material was removed by centrifugation, and the radioactivity in a small portion of the supernatant was determined by liquid scintillation counting in $5 \mathrm{ml}$ of Bray cocktail. The specific activity of $\left[{ }^{14} \mathrm{C}\right]$ leucine in the final peptide $(43 \mathrm{cpm} / \mathrm{nmol})$ was used to calculate the concentration of peptide in solution.

SDS-polyacrylamide gel electrophoresis. Samples were analyzed by electrophoresis through $12.5 \%$ gels containing $0.375 \mathrm{M}$ Tris-hydrochloride ( $\mathrm{pH}$ 8.9), $0.1 \%$ SDS, and $0.1 \% N, N^{\prime}$-methylenebisacrylamide. The stacking gel contained $4 \%$ acrylamide, $0.1 \%$ methylenebisacrylamide, $0.125 \mathrm{M}$ Tris-hydrochloride ( $\mathrm{pH}$ 6.8), and $0.1 \%$ SDS. Electrophoresis was carried out in $0.05 \mathrm{M}$ Tris- $-0.384 \mathrm{M}$ glycine- $0.1 \% \mathrm{SDS}$ at $120 \mathrm{~V}$ for $6 \mathrm{~h}$. The gel was fixed for 1 to $2 \mathrm{~h}$ in $10 \%$ (vol/vol) methanol-10\% (vol/vol) acetic acid, soaked for $1 \mathrm{~h}$ in Enhance (New England Nuclear Corp.) and for $1 \mathrm{~h}$ in water, and dried. An autoradiograph was prepared at $-70^{\circ} \mathrm{C}$ with Kodak XR-5 film and an intensifying screen.

Stocks (30\%, vol/vol) of acrylamide were purified as described by Baron and Baltimore (12).

Coupling of p63(C) and BSA to Affigel. The p63 carboxy-terminal peptide was immobilized on an affinity support by being coupled to Affigel 10 ( $N$-hydroxysuccinimide ester of cross-linked succinyl amino-bisethylamino carboxymethyl agarose carboxamide; BioRad Laboratories). The acidic protein BSA was coupled to Affigel 15 ( $N$-hydroxysuccinimide ester of cross-linked succinyl methylimino-bis-propylamino carboxymethyl agarose carboxamide). In preparation for coupling to BSA, the agarose support was washed on a sintered glass funnel with 3 volumes of isopropanol and 3 volumes of ice-cold distilled water. Protein (400 mg) in 0.5 M HEPES ( $N$-2-hydroxyethyl piperazine- $N^{\prime}$-2-ethanesulfonic acid)-KOH (pH 7.5) was rapidly combined with $22 \mathrm{ml}$ of wet gel (the $N$-hydroxysuccinimide has a very short half-life in aqueous solution) and mixed at room temperature for $16 \mathrm{~h}$. The efficiency of coupling was $\mathbf{9 2 . 8 \%}$. Unreacted groups on the agarose were blocked by reaction with 5 volumes of $1 \mathrm{M}$ ethanolamine-hydrochloride ( $\mathrm{pH} \mathrm{8)}$ for 


$$
\begin{aligned}
& \overbrace{p 63(N)}^{p 63}
\end{aligned}
$$

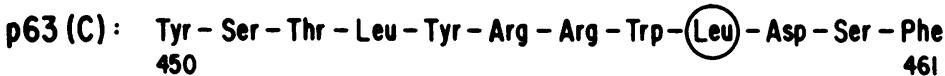

$$
\begin{aligned}
& \text { p63 (N): Asn-A10-Pro - Ser - Lys - Thr - Lys - Lev - Glu - Pro - Ser - Alo - Phe }
\end{aligned}
$$

FIG. 1. Amino acid sequences of the synthetic p63 peptides. The p63 coding region is represented by the horizontal line. ( $\square$ ) Positions within the sequence of the peptides chosen for synthesis. p63 is 461 amino acids in length; p63(N) corresponds to residues 18 through 30, and p63(C) corresponds to residues 450 through 461 . Amino acids labeled with ${ }^{14} \mathrm{C}$ are circled.

$16 \mathrm{~h}$ at room temperature. The resin was washed twice with alternate cycles of $0.2 \mathrm{M}$ glycine-hydrochloride (pH 2.7) and phosphate-buffered saline and then with 3 volumes of $50 \mathrm{mM}$ Tris-hydrochloride ( $\mathrm{pH} \mathrm{7.5)-3} \mathrm{M}$ $\mathrm{NaSCN}$; it was finally equilibrated with phosphatebuffered saline. In preparation for coupling to the carboxy-terminal peptide, Affigel 10 was washed with 3 volumes of dimethyl formamide, in which p63(C) is highly soluble. (Affigel will couple in either aqueous or organic solvents [15]). Sephadex G-25-purified peptide $(9.2 \mathrm{mg})$ in dimethyl formamide was mixed with about $4 \mathrm{ml}$ of wet gel for $20 \mathrm{~h}$ at room temperature. The efficiency of coupling was $75 \%$. Unreacted groups on the agarose were modified with ethanolamine and the peptide-agarose was washed as described above.

Purification of sera by affinity chromatography. A column $(1.5$ by $12.5 \mathrm{~cm})$ of BSA-agarose was connected directly to a smaller column $(1.0$ by $2 \mathrm{~cm})$ containing the p63(C) peptide-agarose. Immune sera (10 to 12 $\mathrm{ml}$ ) were applied to the BSA-agarose. Phosphatebuffered saline was used to wash unbound protein through the first column and onto the affinity column. The absorbance $(280 \mathrm{~nm})$ of eluted protein was measured by passing the eluate through a UVicord II spectrophotometer (LKB Instruments). When protein was no longer detectable in the eluate, the BSAagarose column was disconnected and the peptideagarose was washed with phosphate-buffered saline containing $2 \mathrm{M} \mathrm{KCl}$. Peptide-specific antibodies were finally eluted with $50 \mathrm{mM}$ Tris-hydrochloride ( $\mathrm{pH} 7.5$ )$3 \mathrm{mM}$ NaSCN, concentrated 10 -fold by precipitation with $80 \%$ ammonium sulfate, and dialyzed against 50 mM Tris-hydrochloride (pH 7.5)-50 mM KCl-0.1 mM EDTA. The purpose of the BSA-agarose column was to remove substances which might otherwise have been adsorbed tightly but nonspecifically to the affinity matrix and to remove antibodies raised against the BSA used as carrier in the immunizations. The purified antibodies were tested for retention of biological activity by immune precipitation of p63-containing polypeptides from ${ }^{35} \mathrm{~S}$-labeled cell lysates.

The control antibodies used in these experiments were raised in rabbits injected with a synthetic peptide from Rous sarcoma virus, pp60 ${ }^{\text {src }}$ (peptide sequence, Val-Cys-Lys-Val-Ala-Asp-Phe-Gly) and were a generous gift from Andrew Laudano, Massachusetts Insti- tute of Technology. The antiserum was purified and concentrated as described above.

Preparation of replicase and host factor. Replicase was prepared from poliovirus-infected HeLa cells by a modification of previously published procedures (16, 17 ) as detailed by Baron and Baltimore (in press). Host factor was purified from a cytoplasmic supernatant $(130,000 \times g)$ of uninfected HeLa cells by the procedure of Baron and Baltimore (in press). Assay conditions, detailed more explicitly in the appropriate figure legends, were also those described by Baron and Baltimore (in press).

\section{RESULTS}

Synthesis of peptides. Solid-phase methods $(11,40)$ were used to synthesize an aminoterminal, 13-residue p63 peptide comprising amino acids 18 through 30 of the 461-amino acid p63 sequence, and a second $\mathrm{p} 63$ peptide comprising the carboxy-terminal 12 amino acids [p63(N) and p63(C), respectively]. The sequences correspond to base numbers 6,038 through 6,076 and 7,334 through 7,369 (34) (Fig. 1). The molecular weights of the peptides are $1,390[\mathrm{p} 63(\mathrm{~N})]$ and $1,607[\mathrm{p} 63(\mathrm{C})]$.

The p63(C) sequence was chosen for synthesis because of its terminal location in the polypeptide chain (see Walter et al. [44] for a discussion of this approach). The p63(N) sequence was chosen on the basis of its high content of polar and charged amino acids; these residues, along with the two prolines, are likely to be found on the exterior surface of the protein and hence as part of an antigenic determinant $(6-8,24,36$, 37).

Purified peptides were shown to be of the correct composition by amino acid analysis (Table 1). It should be noted, in particular, that the molar yield of tryptophan in p63(C) $(1.18 \mathrm{~mol} /$ mol of peptide) was in good agreement with the theoretical value of unity, indicating that the precautions taken to prevent oxidation of this 
amino acid were effective. Peptide purity was further confirmed by thin-layer chromatography and high-voltage paper electrophoresis as described by Baron and Baltimore (12).

Antisera raised against the synthetic peptides. The synthetic peptides were separately coupled to BSA by reaction with glutaraldehyde. The low solubility of p63(C) in aqueous solutions above $\mathrm{pH} 5.5$ precluded its coupling by the conventional procedure, and $50 \%$ methanol was included in the buffer (see above for comments on solubility of BSA under these conditions). A radioisotopically labeled amino acid $\left(\left[{ }^{14} \mathrm{C}\right] \mathrm{ala}\right.$ nine for $\mathrm{p} 63(\mathrm{~N})$ and $\left[{ }^{14} \mathrm{C}\right]$ leucine for $\mathrm{p} 63(\mathrm{C})$; circled in Fig. 1) was incorporated into each peptide during its synthesis so that the efficiency of coupling could be monitored. Approximately $6 \mathrm{~mol}$ of p63(N) and $46 \mathrm{~mol}$ of p63(C) were coupled per mole of protein carrier.

Rabbits were immunized with the BSA-p63 peptide conjugates. To determine whether an antibody response to $\mathrm{p} 63(\mathrm{~N})$ had occurred, we assayed for reaction of anti-p63(N) with $\left[{ }^{125} \mathrm{I}\right]$ p63(N) labeled with the Bolton-Hunter reagent. No precipitation of peptide by the sera from immunized animals could be detected either by direct counting of radioactivity in the $S$. aureus pellets or by electrophoresis through $20 \%$ SDS-polyacrylamide gels followed by autoradiography (data not shown). The solubility properties of $\mathrm{p63}(\mathrm{C})$ would have made iodination with chloramine $\mathrm{T}$ or the Bolton-Hunter reagent impracticable, and no attempt was made to label this peptide with ${ }^{125} \mathrm{I}$. We therefore proceeded immediately to immune precipitation from radiolabeled lysates of virus-infected cells with the anti-p63(C) serum.

Recognition of poliovirus-specific polypeptides by the anti-peptide sera. To determine whether authentic p63 as well as poliovirus-encoded polypeptides containing p63-related sequences could be identified in infected cells, we performed immunoprecipitation experiments with the anti-p63(C) sera. Tryptic peptide analysis (results of Ambros, Flanegan, and Baltimore, cited in reference 21) revealed the presence of common sequences in p63 and the larger NCVP 2. A combination of protein and nucleic acid sequence data were used to map p63, NCVP 2 , and the large replicase precursor NCVP $1 \mathrm{~b}$ on the poliovirus genome $(25,39):$ p 63 sequences are contained within NCVP 2, which in turn is contained within NCVP 1b (Fig. 2). NCVP 1b constitutes the carboxy-terminal 55\% (25) of NCVP $0 b$, a single-cleavage product of the progenitor poliovirus protein NCVP $00(10)$. Because NCVP Ob is not normally detectable at all in infected cells and because the level of NCVP $1 \mathrm{~b}$ is rather low, poliovirus-infected cells were labeled with $\left[{ }^{35} \mathrm{~S}\right]$ methionine in the presence of
$\mathrm{Zn}^{2+}$; this metal inhibits many of the proteolytic cleavages which give rise to mature viral gene products (14) and thus allows large precursor polypeptides to accumulate. Lysates from cells infected in the presence or absence of $\mathrm{ZnCl}_{2}$ were examined by electrophoresis through and autoradiography of $12.5 \%$ polyacrylamide gels. It was clear that the $\mathrm{ZnCl}_{2}$ treatment had increased the yield of high-molecular-weight virus-specific proteins (Fig. 3, lanes 1 and 6).

When the lysates were analyzed by immunoprecipitation with anti-p63(C), five proteins labeled in the absence of $\mathrm{ZnCl}_{2}$ were recognized by the immune sera but not the preimmune sera (Fig. 3, lanes 2 and 3): NCVP 1b (molecular weight, 84,000 [25]); NCVP 2 (72,000 [25]); a polypeptide of about 60,000 (tentatively termed pre-p63); p63 (NCVP 4; 52,500 [25]); and NCVP 6b (approximate molecular weight, 30,000 [38]).

A sixth higher-molecular-weight protein was specifically precipitated by anti-p63(C) from extracts of cells infected in the presence of $\mathrm{ZnCl}_{2}$ (Fig. 3, lanes 7 and 8); it appeared to be NCVP Ob $(149,000$ [25]). NCVP 0b and NCVP $1 b$ were also precipitated by antisera raised against $\mathrm{VPg}$ peptides (12). Considerably more NCVP 1b was precipitated from lysates labeled in the presence than in the absence of $\mathrm{ZnCl}_{2}$ (Fig. 3; compare lanes 2 and 3 with lanes 7 and 8), reflecting its increased abundance when proteolytic processing was inhibited. Similarly, these same lysates contained greatly reduced amounts of the lower-

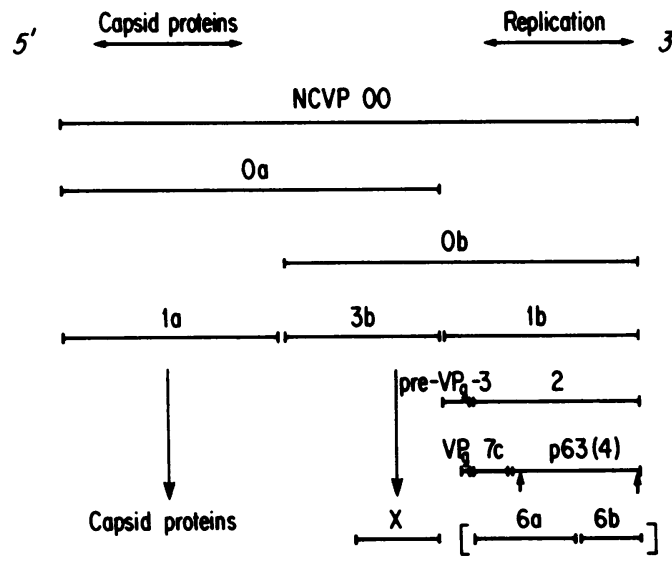

FIG. 2. Cleavage map of poliovirus gene products. The relevant p63-related polypeptides are NCVP 0b, NCVP 1b, NCVP 2, and NCVP 6b. NCVP 6a and 6b are shown in brackets because they are thought to be alternative cleavage products of NCVP 2. Arrows indicate the positions in $\mathrm{p} 63$ of the peptides chosen for synthesis. NCVP $1 \mathrm{~b}$ undergoes proteolysis to VPg, NCVP 7c, and p63; NCVP 7c is believed to be a protease (32). 


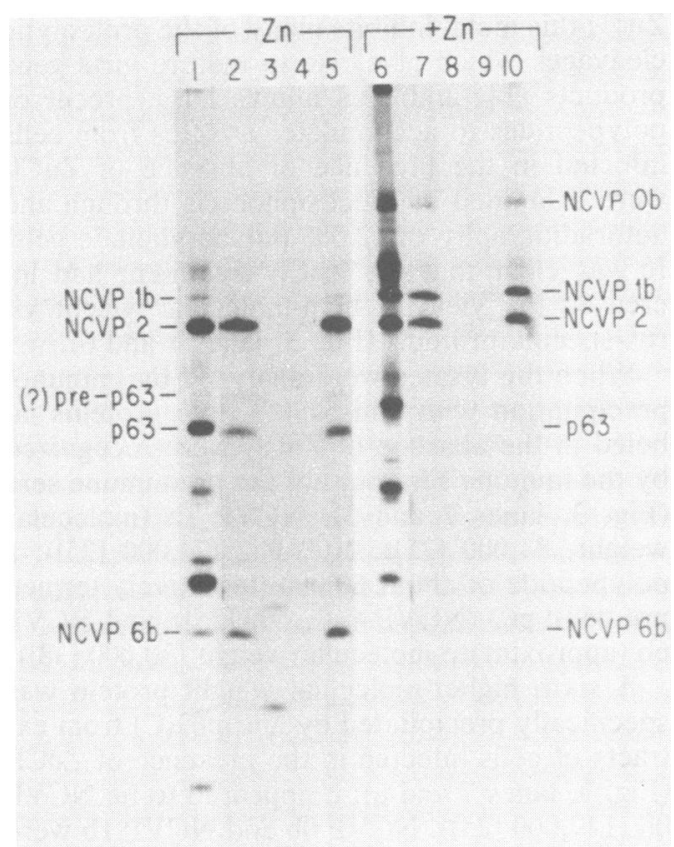

FIG. 3. Reaction with native poliovirus proteins by antibodies raised against p63(C). Portions $(0.5 \mathrm{ml})$ of poliovirus-infected cell lysates labeled with $\left[{ }^{35} \mathrm{~S}\right] \mathrm{me}$ thionine in the presence or absence of $\mathrm{ZnCl}_{2}(0.8 \mathrm{mM})$ were incubated for $1 \mathrm{~h}$ at room temperature with (lanes 2 and 7) $5 \mu$ l of anti-p63(C) or (lanes 3 and 8) $5 \mu l$ of preimmune serum. Specific binding by anti-p63(C) antibody to NCVP 0b, NCVP 1b, NCVP 2, pre-p63, p63, and NCVP 6b was completely inhibited in the presence of $100 \mu \mathrm{g}$ of p63(C) (lanes 4 and 9). Incubation with $100 \mu \mathrm{g}$ of the insulin A chain (lanes 5 and 10) did not interfere with recognition by anti-p63 of poliovirus-specific proteins. Lanes 1 and 5 contain more concentrated samples of total cell lysates and represent 1/20 the amount of material used for incubation with antibody. Antigen-antibody complexes were collected with $S$. aureus as described in the text and subjected to electrophoresis through a $12.5 \%$ SDSpolyacrylamide gel, which was then fixed and fluorographed.

molecular-weight viral proteins, which were scarcely or not at all detectable in the immune precipitates (Fig. 3, lanes 7 and 8).

The anti-p63(C) sera apparently recognized a common antigenic determinant in proteins from poliovirus-infected cell lysates and in the synthetic peptide, because all six proteins were specifically competed with when antibody was incubated with radiolabeled infected-cell extracts in the presence of microgram amounts of p63(C) (Fig. 3, lanes 4 and 9). The insulin A chain at the same concentration did not compete with any of the proteins recognized by antip63(C) (Fig. 3, lanes 5 and 10): the amino- terminal p63 peptide also failed to compete with the proteins precipitated by antibody raised against the carboxy-terminal peptide (data not shown).

Antibodies raised against p63(C) precipitated only p63 and NCVP 2 from highly purified, enzymatically active preparations of replicase labeled with $\left[{ }^{35} \mathrm{~S}\right]$ methionine (data not shown). This enzyme fraction contained large amounts of labeled p63 and NCVP 2 and small amounts of three or four ${ }^{35} \mathrm{~S}$-labeled, lower-molecularweight proteins.

Mock-infected cell lysates were examined for proteins cross-reactive with p63(C). An amount of lysate was analyzed which was 100 times the level necessary to heavily expose the X-ray film (Fig. 4, lane 1). Twice as much anti-peptide serum was incubated with this lysate as was used for the experiments shown in Fig. 3. No proteins were specifically precipitated by antip63(C) (Fig. 4, lanes 2 and 3). Therefore, the

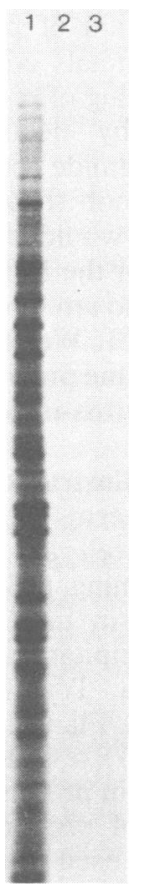

FIG. 4. Incubation of anti-p63 with host cell proteins. Lysates were prepared from mock-infected cells labeled with $\left[{ }^{35} \mathrm{~S}\right]$ methionine, and portions $(1 \mathrm{ml})$ were incubated with $10 \mu \mathrm{l}$ of anti-p63(C) serum (lane 2) or preimmune serum (lane 3 ) for $1 \mathrm{~h}$ at room temperature. After a further $1 \mathrm{~h}$ of incubation $\left(4^{\circ} \mathrm{C}\right)$ with $100 \mu \mathrm{l}$ of a $10 \%(\mathrm{vol} / \mathrm{vol})$ suspension of $S$. aureus, the precipitates were processed and subjected to electrophoresis through a $12.5 \%$ SDS-polyacrylamide gel. Lane 1: Sample of mock-infected cell lysate (1/100 the amount of material used in the immunoprecipitations). 

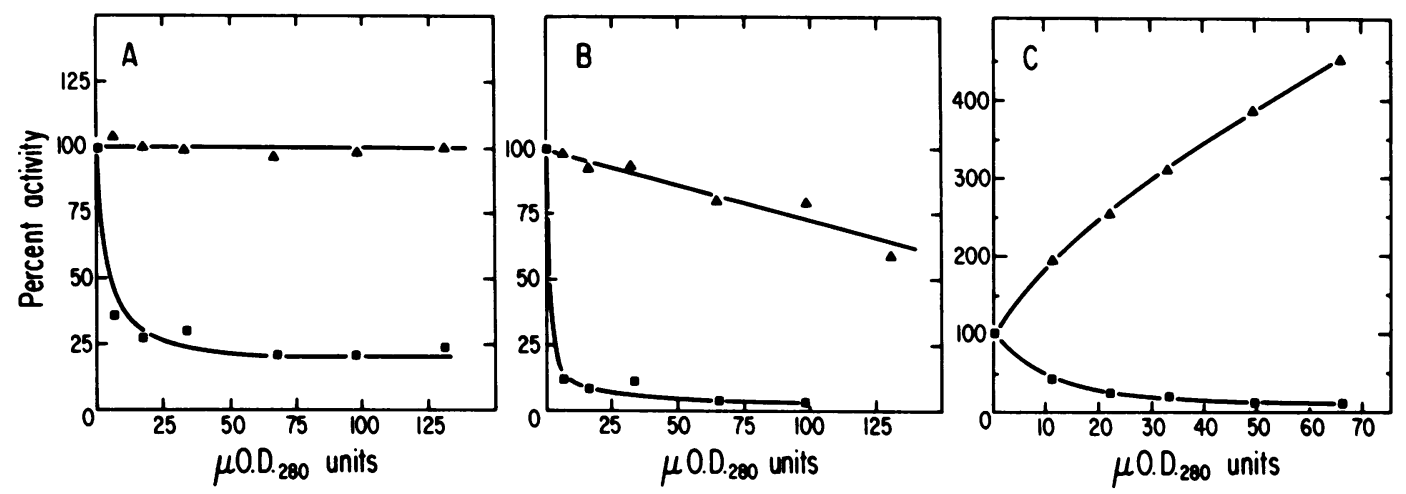

FIG. 5. Inhibition of poliovirus polymerase activities by affinity-purified anti-p63(C). Approximately $0.3 \mu \mathrm{g}$ of replicase-poly(U) polymerase was incubated for $60 \mathrm{~min}$ at $0^{\circ} \mathrm{C}$ with the indicated number of $\mu \mathrm{OD}$ units (see the text for definition) of anti-pp60src $(\Delta)$ or anti-p63(C) $(\square)$. The appropriate components of the poly(U) polymerase (panel A), host factor-stimulated replicase (panel B), or oligo(U)-stimulated replicase (panel C) reactions were then added, and incubation was continued at $30^{\circ} \mathrm{C}$ for $30 \mathrm{~min}(\mathrm{~A})$ or $60 \mathrm{~min}$ (B and C). The radioactivity incorporated into acid-insoluble polymer was determined as described in the text. Each assay contained $20 \mu \mathrm{Ci}$ of $\left[\alpha-{ }^{32}\right.$ P]UTP $(450 \mathrm{Ci} / \mathrm{mmol})$. Fraction $\mathrm{V}$ host factor $(1 \mu \mathrm{l})$ was used for the experiment represented in panel B. Oligo(U) was added to 30 -fold molar excess $(6 \mathrm{pmol})$ over template RNA $(0.2 \mathrm{pmol})$ in the experiment shown in panel C.

anti-p63(C) sera recognize a particular subset of completely virus-specific proteins.

Consistent with their failure to precipitate radiolabeled p63(N), sera from rabbits immunized with the amino-terminal peptide did not react specifically with any poliovirus-specific proteins (data not shown).

Inhibition of replicase and poly $(U)$ polymerase activities by anti-p63(C). Poliovirus replicase and poly(U) polymerase activities were nonspecifically inhibited by unpurified serum, and it was therefore necessary to subject immune and control sera to affinity chromatography. The carboxy-terminal p63 peptide was coupled to Affigel, an agarose derivative. Serum was first applied to a large column of BSA-agarose (see above) to remove antibodies raised against BSA (with which the peptide had originally been coupled before injection into rabbits) and other proteins which might have bound tightly and nonspecifically to the affinity column. Protein which flowed through the BSA-agarose column was conducted directly to a smaller affinity column, to which anti-p63(C) antibodies then bound.

Retention of specific antibody activity was demonstrated by immunoprecipitation of p63 and p63-related polypeptides from labeled lysates of infected cells (data not shown). Precipitation of ${ }^{125}$ I-labeled peptide would have permitted us to quantitate the recovery of activity; but, for the reasons given above, the carboxy-terminal peptide could not be labeled with iodine.

Antibodies raised against p63(C) specifically inhibited not only poly(U) polymerase activity
(Fig. 5A) but also the host factor- and oligo(U)stimulated replicase reactions (Fig. 5B and C, respectively). The controls used in early experiments were preimmune sera which had been subjected to the same chromatographic procedures as the anti-p63(C) sera. These protein fractions did not inhibit the poliovirus polymerases (data not shown). Our concern that the apparently specific inhibition by the purified immune sera might be due instead to nonspecific inhibition by immunoglobulin led us to the use of an irrelevant antiserum as a control. Thus, antiserum from a rabbit immunized with a synthetic peptide of the Rous sarcoma virus pp60 $0^{\text {src }}$ was purified by sequential chromatography on BSAagarose and pp60 ${ }^{s r c}$-agarose under exactly the same conditions as described for the p63(C) antisera. Optical densities of the purified, concentrated antisera were measured at $280 \mathrm{~nm}$ $\left(O D_{280}\right)$, and equal numbers of units (here expressed as $\mu \mathrm{OD}_{280}$ units) were added to parallel polymerase assays. Anti-pp $60^{\text {src }}$ had little effect on either the poly(U) polymerase or the replicase-host factor reaction (Fig. 5A and B), but stimulated the replicase reaction primed by oligo(U) (Fig. 5C), possibly by removing or masking some inhibitory substance. Anti-p63(C) inhibited all three reactions (Fig. 5A-C).

The antisera precipitated only p63 and NCVP 2 from radiolabeled preparations of replicase (see above). Poly(U) polymerase and replicase have always been found to copurify $(16,17,22$, 43), and the two activities have been shown to be associated with p63 but not with NCVP 2 (43). Our immunological experiments therefore 
provide strong evidence that replicase and poly(U) polymerase activities are properties of the same virus-encoded polypeptide and that this polypeptide must be $\mathrm{p} 63$.

\section{DISCUSSION}

The solutions to many problems in protein biochemistry are greatly facilitated by the availability of specific antibodies. Our own interest in the structure and function of the poliovirus replicase has led us to the preparation of antibodies against $\mathrm{p} 63$, the protein with which virusspecific, RNA-dependent RNA polymerase activity is associated (43). Highly purified preparations of replicase contain such small amounts of p63 that the simple immunization of experimental animals is impracticable (a Coomassie blue-stainable polypeptide which comigrates with $\left[{ }^{35}\right.$ S]methionine-labeled p63 on SDS-10\% polyacrylamide gels is in fact a host cell protein and can be resolved from p63 on a $7.5 \%$ gel; unpublished data). Therefore, we used solid-phase methods to synthesize two peptides of p63, one from the amino terminus and one from the carboxy terminus (Fig. 1).

The amino terminus of $\mathrm{p} 63$ was pinpointed by a combination of nucleic acid and protein sequencing methods $(25,39)$, revealing that the coding region of $\mathrm{p} 63$ represents the carboxyterminal $70 \%$ of NCVP 2. NCVP 2 itself was shown by pactamycin mapping to constitute the most 3'-proximal of the viral gene products (42). The molecular weight estimate $(63,000)$ obtained by gel electrophoresis (21) implies that the p63 carboxyl terminus must extend almost to the end of genomic coding sequence, terminated by two stop codons within 71 bases of the poly $(A)$ tail $(25,26,34)$. The immunoprecipitation data presented here for anti-p63(C) (Fig. 3) provide clear evidence for the assignment of the p63 carboxyl terminus to the last stretch of translatable genomic sequence (however, the molecular weight of p63 is actually only about 53,000 [25]). They also confirm the relationship between NCVP $0 b$, NCVP 1b, NCVP 2, and p63 (Fig. 2) and thus support earlier conclusions drawn from other types of experiments. Finally, they indicate that the major open reading frame in the poliovirus genome deduced by Kitamura et al. (25) and Racaniello and Baltimore (34) must be correct.

Pulse-chase experiments suggested that there existed two alternative sites for the cleavage of NCVP 2 (or its precursor, NCVP 1b), giving rise either to NCVP 7c and p63 or else to NCVP 6a and $6 \mathrm{~b}$ (38) (Fig. 2). The specific precipitation of NCVP 6b by anti-p63(C) sera confirms that this protein is encoded within the $3^{\prime}$ end of the genome. It is not clear whether NCVP $6 \mathrm{~b}$ is ever generated directly from p63 itself. Thus far, no enzymatic activity has been attributed to this protein.

The identity of the 60,000 -molecular-weight polypeptide recognized by anti-p63(C) is unknown. It is possible that the 60,000 protein was precipitated as part of a complex with p63 or other p63-related gene products, but its appearance in the immune precipitates was reproducible, and the detergent composition of the phospholysis buffer should not favor the formation of aggregates or complexes. Nevertheless, this protein was precipitated in only very small quantities, and our designation of this protein as prep63 must be considered tentative. Etchison and Ehrenfeld (18) have also reported the existence of a putative replicase protein precursor which accumulates in poliovirus-infected cells in the presence of a protease inhibitor (iodoacetamide) and which has tryptic peptides in common with the replicase protein. The two polypeptides described by these workers (termed NCVP $4 a$ and 4b) may correspond to our pre-p63 and p63, respectively.

Interestingly, p63(N) failed to stimulate an immune response in spite of the fact that it seemed to be an ideal candidate for an antigen. The non-immunogenicity of p63(N) may be the result of immunological tolerance, possibly involving a $T$ cell-mediated suppression reaction. It is also noteworthy that p63(C) successfully induced the production of antibodies despite its very poor solubility in water. This result suggests that hydrophilicity is not a necessary condition for the induction of an immune response by a peptide antigen and is consistent with the finding that some regions on the external surface of a protein-where antigenic determinants should reside $(6-8,24,35)$-are relatively hydrophobic $(27,28,37)$.

A poly $(U)$ polymerase activity has been found to copurify with the poliovirus replicase $(16,17$, $22,43)$. These polymerase activities have furthermore been shown to copurify with the viral protein p63; NCVP 2 contains neither activity $(22,43)$. The kinetics of appearance of poly(U) polymerase (20) and replicase (16) activities in the infected cell are very similar, suggesting that the two enzymes are very closely related, at least in function. The inhibition by anti-p63(C) of both activities in highly purified enzyme fractions provides strong evidence for the association of these two polymerases with a single protein and supports conclusions drawn on the basis of protein purification alone.

\section{ACKNOWLEDGMENTS}

We thank Andrew Laudano for many helpful discussions and for his active interest in the work reported here. We thank Michael Rosenblatt for advice concerning the synthesis and cleavage of tryptophan-containing peptides and for allowing 
us to use his laboratory's HF line. Finally, we thank John Raffensperger for assistance with the HF cleavage procedure.

M.H.B. is a predoctoral scholar of the Insurance Medical Scientist Scholarship Fund and a fellow of the Danforth Foundation. D.B. is an American Cancer Society Professor of Microbiology. This research was supported by Public Health Service grants from the National Institute of Allergy and Infectious Disease and from the National Cancer Institute.

\section{LITERATURE CITED}

1. Anderer, F. A. 1963. Preparation and properties of an artificial antigen immunologically related to tobacco mosaic virus. Biochem. Biophys. Acta 71:246-248.

2. Anderer, F. A., and H. D. Schlumberger. 1965. Properties of different artificial antigens immunologically related to tobacco mosaic virus. Biochem. Biophys. Acta 97:503509.

3. Anderer, F. A., and H. D. Schlumberger. 1966. Crossreactions of antisera against the terminal amino acid dipeptide of tobacco mosaic virus. Biochem. Biophys. Acta 115:222-224.

4. Arnon, R., E. Maron, M. Sela, and C. B. Anfinsen. 1971. Antibodies reactive with native lysozyme elicited by a completely synthetic antigen. Proc. Natl. Acad. Sci. U.S.A. 68:1450-1455.

5. Arnon, R., and M. Sela. 1969. Antibodies to a unique region in lysozyme provoked by a synthetic antigen conjugate. Proc. Natl. Acad. Sci. U.S.A. 62:163-170.

6. Atassi, M. Z. 1975. Antigenic structure of myoglobin: the complete immunochemical anatomy of a protein and conclusions relating to antigenetic structures of proteins. Immunochemistry 12:423-434.

7. Atassi, M. Z., and C. L. Lee. 1978. The precise and entire antigenic structure of native lysozyme. Biochem. J. 171:429-434.

8. Atassi, M. Z., and B. J. Saplin. 1968. Immunochemistry of sperm whale myoglobin. I. The specific interaction of some tryptic peptides containing all the reactive regions of the antigen. Biochemistry 7:688-698.

9. Baltimore, D., M. Girard, and J. E. Darnell. 1966. Aspects of the synthesis of poliovirus RNA and the formation of virus particles. Virology 29:179-189.

10. Baltimore, D., M. F. Jacobson, J. Asso, and A. S. Huang. 1969. The formation of poliovirus proteins. Cold Spring Harbor Symp. Quant. Biol. 34:741-751.

11. Barany, G., and R. B. Merrifield. 1980. Solid-phase peptide synthesis, p. 1-284. In E. Gross and J. Meienhofer (ed.), The peptides: analysis, synthesis and biology, vol. 2. Academic Press, Inc., New York.

12. Baron, M. H., and D. Baltimore. 1982. Antibodies against the chemically synthesized genome-linked protein of poliovirus react with native virus-specific proteins. Cell 28:395-404.

13. Bolton, A. E., and W. M. Hunter. 1973. The labeling of proteins to high specific radioactivities by conjugation to a ${ }_{125} \mathrm{I}$-containing acylating agent. Biochem. J. 133:529-538.

14. Butterworth, B. E., and B. Korant. 1974. Characterization of the large picornaviral polypeptides produced in the presence of zinc ion. J. Virol. 14:282-291.

15. Cuatrecasas, P., and I. Parikh. 1972. Adsorbents for affinity chromatography: use of $\mathbf{N}$-hydroxy succinimide esters of agarose. Biochemistry 11:2291-2299.

16. Dasgupta, A., M. H. Baron, and D. Baltimore. 1979. Poliovirus replicase: a soluble enzyme able to initiate copying of poliovirus RNA. Proc. Natl. Acad. Sci. U.S.A. 76:2679-2683.

17. Dasgupta, A., P. Zabel, and D. Baltimore. 1980. Dependence of the activity of the poliovirus replicase on a host cell protein. Cell 19:423-429.

18. Etchison, D., and E. Ehrenfeld. 1980. Viral polypeptides associated with the RNA replication complex in poliovirus-infected cells. Virology 107:135-143.

19. Fearney, F. J., C. Y. Leung, J. D. Young, and E. Benja- mini. 1971. The specificity of antibodies to a peptide determinant of the tobacco mosaic virus protein induced by immunization with the peptide conjugate. Biochem. Biophys. Acta 243:509-514.

20. Flanegan, J. B., and D. Baltimore. 1977. Poliovirus-specific primer-dependent RNA polymerase able to copy poly(A). Proc. Natl. Acad. Sci. U.S.A. 74:3677-3680.

21. Flanegan, J. B., and D. Baltimore. 1979. Poliovirus polyuridylic acid polymerase and RNA replicase have the same viral polypeptide. J. Virol. 29:352-360.

22. Flanegan. J. B., and T. A. Van Dyke. 1979. Isolation of a soluble and template-dependent poliovirus RNA polymerase that copies virion RNA in vitro. J. Virol. 32:155-161.

23. Furie, B., A. N. Schechter, D. H. Sachs, and C. B. Anfinsen. 1974. Antibodies to the unfolded form of a helixrich region in staphylococcal nuclease. Biochemistry 13:1561-1566.

24. Hopp, T. P., and K. R. Woods. 1981. Prediction of protein antigenic determinants from amino acid sequences. Proc. Natl. Acad. Sci. U.S.A. 78:3824-3828.

25. Kitamura, N., B. L. Semler, P. G. Rothberg, G. R. Larsen, C. J. Adler, A. J. Dorner, E. A. Emini, R. Hanecak, J. J. Lee, S. Van der Werf, C. W. Anderson, and E. Wimmer. 1981. Primary structure, gene organization and polypeptide expression of poliovirus RNA. Nature (London) 291:547-553.

26. Kitamura, N., and E. Wimmer. 1980. Sequence of 1060 3'terminal nucleotides of poliovirus RNA as determined by a modification of the dideoxynucleotide method. Proc. Natl. Acad. Sci. U.S.A. 77:3196-3200.

27. Klotz, I. M. 1970. Comparison of molecular structures of proteins: helix content; distribution of apolar residues. Arch. Biochem. Biophys. 138:704-706.

28. Lee, B., and F. M. Richards. 1971. The interpretation of protein structures: the estimation of static accessibility. $\mathrm{J}$. Mol. Biol. 55:379-400.

29. Lerner, R. A., N. Green, H. Alexander, F. T. Liu, J. G. Sutclife, and T. M. Shinnick. 1981. Chemically synthesized peptides predicted from the nucleotide sequence of the hepatitis B virus genome elicit antibodies reactive with the native envelope protein of Dane particles. Proc. Natl. Acad. Sci. U.S.A. 78:3403-3407.

30. Maron, E., C. Shiozawa, R. Arnon, and R. Sela. 1971. Chemical and immunological characterization of a unique antigenic region in lysozyme. Biochemistry 10:763-771.

31. Moroder, L., A. Hallett, E. Wünsch, O. Keller, and G. Wersin. 1976. Di-tert-butyldicarbonat-ein vorteilhaftes Reagenz zur Einführung der tert-ButyloxycarbonylSchutzgruppe. Hoppe-Seyler's Z. Physiol. Chem. 357:1651-1653.

32. Palmenberg, A. C., M. S. Pallansch, and R. Rueckert. 1979. Protease required for processing picornaviral coat protein resides in the viral replicase gene. J. Virol. 32:770778.

33. Pozdnev, V. F. 1974. Use of di-tert-butyl pyrocarbonate to obtain $N$-tert-butoxycarbonyl derivatives of amino acids. Chem. Nat. Compd. (Engl. Transl. Khim. Prir. Soedin.) 10:782-784.

34. Racaniello, V. R., and D. Baltimore. 1981. Molecular cloning of poliovirus cDNA and determination of the complete nucleotide sequence of the viral genome. Proc. Natl. Acad. Sci. U.S.A. 78:4887-4891.

35. Reichlin, M. 1975. Amino acid substitution and the antigenicity of globular proteins. Adv. Immunol. 20:71-123.

36. Richardson, J. S. 1981. The anatomy and taxonomy of protein structure. Adv. Protein Chem. 36:167-339.

37. Rose, G. D., and S. Roy. 1980. Hydrophobic basis of packing globular proteins. Proc. Natl. Acad. Sci. U.S.A. 77:4643-4647.

38. Rueckert, R. R., T. J. Matthews, O. M. Kew, M. Pallansch, C. McLean, and D. Omilianowski. 1979. Synthesis and processing of picornaviral protein, p. 113-125. In R. Perez-Bercoff (ed.), The molecular biology of picornaviruses. Plenum Publishing Corp., New York.

39. Semler, B. L., C. W. Anderson, N. Kitamura, P. G. 
Rothberg, W. L. Wishart, and E. Wimmer. 1981. Poliovirus replication proteins: RNA sequence encoding P3-1b and the sites of proteolytic processing. Proc. Natl. Acad. Sci. U.S.A. 78:3464-3468.

40. Stewart, J. M., and J. D. Young. 1969. Solid phase peptide synthesis. W. H. Freeman and Co., San Francisco.

41. Sutclifie, J. G., T. M. Shinnick, N. Green, F. T. Liu, H. L. Niman, and R. A. Lerner. 1980. Chemical synthesis of a polypeptide predicted from nucleotide sequence allows detection of a new retroviral gene product. Nature (London) 287:801-805.

42. Taber, R., D. Rekosh, and D. Baltimore. 1971. Effect of pactamycin on synthesis of poliovirus proteins: a method for genetic mapping. J. Virol. 8:395-401.

43. Van Dyke, T. A., and J. B. Flanegan. 1980. Identification of poliovirus polypeptide p63 as a soluble RNA-dependent RNA polymerase. J. Virol. 35:732-740.

44. Walter, G., K. H. Scheidtmann, A. Carbone, A. P. Laudano, and R. F. Doolittle. 1980. Antibodies specific for the carboxy-and amino-terminal regions of simian virus 40 large tumor antigen. Proc. Natl. Acad. Sci. U.S.A. 77:5197-5200.

45. Young, N. S., J. G. Curd, A. Eastlake, B. Furie, and A. N. Schechter. 1975. Isolation of antibodies specific to sickle hemoglobin by affinity chromatography using a synthetic peptide. Proc. Natl. Acad. Sci. U.S.A. 72:4759-4763. 